\begin{tabular}{|c|c|c|c|c|c|c|}
\hline \multirow{4}{*}{ Impact Factor: } & ISRA (India) & $=3.117$ & SIS (USA) & $=0.912$ & ICV (Poland) & $=6.630$ \\
\hline & ISI (Dubai, UAE & $=0.829$ & РИНЦ (Russia) & $=0.156$ & PIF (India) & $=1.940$ \\
\hline & GIF (Australia) & $=0.564$ & ESJI (KZ) & $=8.716$ & IBI (India) & $=4.260$ \\
\hline & JIF & $=1.500$ & SJIF (Morocco) & $=5.667$ & OAJI (USA) & $=0.350$ \\
\hline
\end{tabular}

\section{SOI: $1.1 /$ TAS $\quad$ DOI: $10.15863 /$ TAS International Scientific Journal Theoretical \& Applied Science}

\author{
p-ISSN: 2308-4944 (print) e-ISSN: 2409-0085 (online) \\ Year: 2019 Issue: $05 \quad$ Volume: 73
}

Published: $30.05 .2019 \quad \underline{\text { http://T-Science.org }}$
QR - Issue

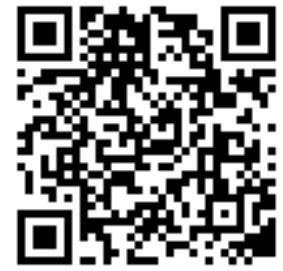

Ayimxan Eshniyozova
The teacher of
the Chemical Technology Institute, Uzbekistan
dokma@ bk.ru

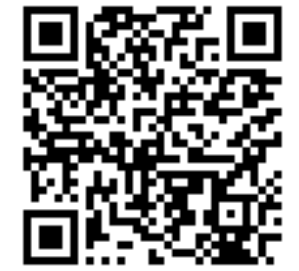

\title{
UP DATES IN A NARRATIVE GENRE
}

Abstract: The article gave an introduction to the historical basics of the story genre, stages of development and researches in this genre in Uzbek literature. The concepts about this genre were summarized. Changes in the nature of the genre were indicated to be periodic. The influence of narratives in the world literature on the development of Uzbek ones, novelties in writing narratives during the period of independence years and researches of Uzbek narration are analyzed.

Key words: a narrative genre, the genre, the plot of a work, composition, a hero.

Language: English

Citation: Eshniyozova, A. (2019). Up dates in a narrative genre. ISJ Theoretical \& Applied Science, 05 (73), 556-559.

Soi: http://s-o-i.org/1.1/TAS-05-73-86 Doi: crossef https://dx.doi.org/10.15863/TAS.2019.05.73.86

\section{Introduction}

The narrative is a major and painful kind of the current literary genre. This genre is a literary historic process that has acquired artistic perfection. The one runs its own artistic role within the novel and story line as the medium genre of epic poetry. The main focus is on the extent to which this genre is preserved as its one is determined in literature. Some of the views of literary scholars on the genre features of this have already been discussed and debated. The genre is in constant development but its determinants do not change. In all the definitions given to the narrative genre, epic scale, plot construction, heroic image are the basic measure.

\section{Materials and Methods}

A number of the researches were conducted by V. Belinskiy, V. Fisher, S. Lixachev, N. Nadejdin, V. Golovko, V Kojinov in the Russian literature and I. Sulton, M. Kushjonov, O. Sharafiddinov, U. Normatov, B. Nazarov, S. Mirvaliev, B. Sarimsoqov, A. Rasulov, A. Abrorov, A. Ulug'ov, D. Kurbonov in the Uzbek literature.

V. G. Belinskiy, the Russian literary scholar described the genre as follows: "The narrative is a short-scale image about the fate of a human and the same as the novel. It is only in small volumes and the size of the work is determined according to the essence of the content". [3. 271]. D. S. Lixachev stated that the narrative is shorter than the novel and there are fewer characters in it but the plot is concise, even fast ending.[4. 3]. When N. Nadejdin said that the narrative is an endless story of a human destiny, it was described by I. Timofeev to differ from the story by describing several episodes as a medium epic form. He said: "The narrative is dismantled more shortly and simply than the novel. It is often a chronic character of the plot and the narrator's speech is heard throughout the whole work. The essence of the genre is to determine the nature, the structure of the work and the art critique." According to N. Gulyaev, Berkovskiy, V. Kojinov, the narrative is quiet and epic trend of the life. G. L. Abramov stated that it is sophisticated epic form combining a number of events in the discovery of complex social phenomena and the number of characters involved in the narrative story is considerably higher. [1. 279.] Shupilova said: That one is a medieval episode and it covers many aspects of life but its size is smaller than the novel. The narrative story is characterized by a complex plot, phenomenon and a lot of characters. [12. 197-198.] According to the Russian scientist, the narrative is a middle epic type of literary literature and between the novel and the story. Events are widely and broadly in it. The story line is intended to reflect events in the lives of two main heroes with a great number of characters in the plot. [7. 255.]

Izzat Sulton, one of the Uzbek literary scholars, gives a similar comment about the narrative: "Works of the narrative story are typical of the fate of a person and several related people whose meanings are depicted in the average but do not make it difficult to 


\begin{tabular}{|c|c|c|c|c|c|c|}
\hline \multirow{4}{*}{ Impact Factor: } & ISRA (India) & $=3.117$ & SIS (USA) & $=0.912$ & ICV (Poland) & $=6.630$ \\
\hline & ISI (Dubai, UAI & $=0.829$ & РИНЦ (Russia & $=0.156$ & PIF (India) & $=1.940$ \\
\hline & GIF (Australia) & $=0.564$ & ESJI (KZ) & $=8.716$ & IBI (India) & $=4.260$ \\
\hline & JIF & $=1.500$ & SJIF (Morocco & $=5.667$ & OAJI (USA) & $=0.350$ \\
\hline
\end{tabular}

imagine a broad spectrum of life. [8. 170.] In many studies it is possible to observe that the definition given to the genre is largely based on the shape and is considered as the basic dimension of the genre of the narrative story. U. Normatov, the literary scholar pays a great attention to the meaning: "The narrative story is a tuneful genre with its nature, its best examples can be compared to the singular melody. There is a main problem regardless of fewer or more number of characters, longer or shorter events and character's fate, spirit and temper are analyzed from the point of view of the major problem. The narrative genre is different from the novel according this aspect. [6. 55.] In our opinion, it is the right way to explore the nature of the genre.

A. Abrorov who made research on the narrative described that one of the narrative genre is the illustration of what happened in the life of a single main hero in the work and also the true character of life with the fate of the protagonist. [2. 52.] A. Ulugov said: "Two features of the narrative story are important in its development. Although one is relatively compact in relation to the novel, it is deeply and extensively covered by social life events." [10. 6.]

A. Kozixujaev tried to describe the features of the genre perfectly: "The narrative story describes such events that it can not be drama or novel. However, a significant moment of life is found in it. The narrative is able to capture real great events in its some pages." [13. 214.]

It is clear that the essence of the narrative plot is not an adventure of the individual hero throughout the life but events of a particular era of the heroic life. The final conclusion about it is not depend on the size but rather the scope of events, the relative easier one of duration than the novel and the more complex one than the story. The narrative is between story and novel according to its genre character. When there is the only event of the hero's life in the story, a great period in the complex social relation system of the character can be seen in the novel but a stage of his/ her life is written in the narrative. There is an event in the focus of the story and the world perceived by the means of the hero in the novel. The hero is the target for the narrative story. Therefore all events are arranged around the hero, its plot is not vast as the novel. In order to explore the character of the leading hero the writer combines events into a single center.

M. V. Golovko has such meditation about the nature of narrative genre: "The history of the narrative story leads to serious problems for the research. This genre is completely changeable. The line between the story and the narrative one, the one and the novel is frequently changed. The narrative story includes different work between story and novel. It is characteristic for this to have constant change between them. I. Sulton, the literal scientist explains this feature so: "Neither genus nor genre may be seen purely. The combination of them at a certain level is a characteristic feature of literary creativity. [9. 306.]

D. Kuronov's ideas are based on the discovery of the epic genre: For the novelist the character is a mean to perceive the world, a target for the narrator but the event is one for the writer in the story. [14. 373.]

In general we can emphasize that the hero is in the center of the narrative. The writer pays a great attention to him/her in the literal construction of it. It introduces the concept of artistic reality within a creative person. There are events like these that are not enough for the drama and the novel is not the same but they are deeply ingenious bringing an endless to the ages. The narrative story can include such events. It is concise, light, essentially deep and reflects real happenings.

It came from the Arabic language and according to the linguistic meaning, it is intended to describe a specific period of life as well as activity of one or another person. It is one of the most widely circulated genres not only in Uzbek but also in the literature of the peoples of the Near and Middle East. Thus, the following two descriptions which indicate its essence are given in the dictionary of terms of literature.

1) Narrative is popular folklore and literary works in the Near and Middle East.

2) It is longer than the story, shorter than the novel, in most cases the works of art are based on the main heroic adventure in the modern Uzbek prose. These works are identical to the narrative genre in terms of their nature, genre capabilities, artistic principles and methods.

In literature narrative and the term "povest" are used equally in the Uzbek language. [15. 169.]

These concepts are called a specific genre. In particular, S. Mirvaliev described the two terms as different genres in his book named "the Uzbek novel" The narrative is an independent genre between story and "povest". [5. 277.] M. Kushjonov has the same idea about this genre as S. Mirvaliev. He admits that it is a genre that is smaller than "povest" in size but more rapidly describing the events with dramatic incisive details. U. Normatov tries to prove that these arguments are unfounded, the compact type of "povest" has not appeared these days, it has existed since ancient time. In the $1930 \mathrm{~s}$ a number of those written in the Uzbek prose such as "Obid ketmon", "Sudxurning o'limi", "Yodgor", "Tirilgan murda". The two terms are used as the same meaning and it is not correspond to use them in different meaning. [6. 51.] A. Ulugov, the literal critic, explains that they are the same genre. These two terms mutually equivalent. Therefore, instead of "povest" can be used narrative. It is argumentative to say that a new genre has appeared in reference to the dimensions of the volume. [11. 13.] 


\begin{tabular}{|c|c|c|c|c|c|c|}
\hline \multirow{4}{*}{ Impact Factor: } & ISRA (India) & $=3.117$ & SIS (USA) & $=0.912$ & ICV (Poland) & $=6.630$ \\
\hline & ISI (Dubai, UAI & $=0.829$ & РИНЦ (Russia & $=0.156$ & PIF (India) & $=1.940$ \\
\hline & GIF (Australia) & $=0.564$ & ESJI (KZ) & $=8.716$ & IBI (India) & $=4.260$ \\
\hline & JIF & $=1.500$ & SJIF (Morocco & $=5.667$ & OAJI (USA) & $=0.350$ \\
\hline
\end{tabular}

The literary critic Kuronov did not consider these notions as one genre but emphasized that there is no basis for the interpretation of a particular genre. There is no need to use synonyms as a single genre. We have to classify the narrative story as a separate genre. Firstly, it emerged as the natural act of epic development. Secondly, story-narrative one -novel trilogy is the core of the epic genre. The narrative story in the center of the trilogy is literally artistic so it can be used instead of both ones. [14. 377.]

D. Kuronov emphasized the importance of the stories about prophets in the development of the narrative story. Each episode reflects the spirits of the soul and literal thought of the person living in it as well as other genre. The term "folk books" which is widely used in scientific literature is a synonymic genre in of the narrative one. Jirmunskiy and $\mathrm{H}$. Zaripov say that they there were special narrators in cities and villages and popular works in their repertoire were called "folk books", "folk novel" which are a sample of a short genre now.

We must divide the narrative genre into four steps:

a) the narrative developed in folklore.

b) the written classical narration.

c) the narration in the former Soviet Union.

d) the world realistic and modern narration.

In Sadriddin Ayniy's works such as "Buxoro jallodlari", "Odina", "Qulbobo" we find that the first examples of the narrative stories are not the individual personality but rather the focus of attention on the social scene and the life of heroes. The main condition of the genre was to cover the spiritual image of a person by analyzing the nature and spirit of the hero. We can see the genre transformation, carrying out the burden of the genre and improvement in the genre in the narrative stories like "Obid ketmon", "Shum bola", "Sudxurning o'limi" written in the 1930 s. From the second half of the $1980 \mathrm{~s}$ to the present day the principle of modernization is based on realistic traditions. In such works there are a number of features, such as the myth, the mind, the human imagination, the interpretation, the internal monologue, the chronology, the heroes' uncertainty, the desire to communicate with the reader.

Under the influence of the world literature, genre updates, the revival style, the introduction of the mosaic method, the absurd hero, the logic of the mind, not the heroic movement in the social life but the heroic image of the hero who is struggling with his own internal self, the pioneer in the purity, the consciousness of the human being as art arena in Uzbek literature. On the eve of Independence and during the period of Independence our writers made artistic and methodical updates and created classical examples in this genre. A lot of writers like $\mathrm{N}$. Norkobilov, K. Norkulov, N. Eshonkul, E. Azam, Sh. Bo'taev, X. Do'stmuhammedov, U. Hamdam made a significant contribution to the development of the narrative genre.

N. Normurodov's works which have made a worthy contribution to the development of the literature in the period of Independence describe the artistic interpretation of the nature and human relationships, the relationship between man's self and destiny, his attitude towards religious conflicts. His works reflect the nature of the mountains and the lives of mountain people. His heroes are mountainous, proud, charming but united by their many features. They are literally unkempt, rude, speak shortly without thinking but each one is magnificent like a grass-rooted, ageless stone. They are diligent, firm, genius but proud, affectionate as well as ready to sacrifice for the sake of their people, nation.

The red rope is the characteristic of the Uzbek nation's courage and fidelity in the work by N. Norkobil. In his narrative stories the rock, the stone, the bear, the dog and the human are described in the close relationship. The author brought a new tune to the narrative genre, reflecting experiences of heroes who were looking for ointment in their suffering.

Kuchkor Norkobilov described literally death and life, human and war, also war is a great disaster in his narratives. All his works are about rebellion against the Afghan war and the former Soviet government's wrong policy. The writer's creative works appear in the tragedy of the Afghan war, the manifestation of the human spirit and the spiritual depression. Heroes feel terrible horrors when they face the terrible moment of death and desolation. The manifestation of the human, moral appearance, brutal characters, reflecting his / her personality during the war years are described in it. In the narrative he illustrated the cruelty of the war in Afghanistan, young men standing motionless between death and life. They survived the war but their hearts were in depression.

Erkin Azam did a great contribution in the development of Uzbek narrative. The spirit of irony is on the top steeps of his works. The writer laughed at the unsuitable way of life, livelihood and wanted to point to its destructive situation in addition, to invigorate the community.

\section{Conclusion}

The well-known writer Khurshid Dustmuhammad also has a special place in the new stage of the narrative genre. He addresses images based on symbolism in his almost every aspect. Every detail used contains a great meaning and content. The writer uses the human mind as an art space. Readers does not succumb to the hero, but interacts with his thought and argues with his one. He observes dark and bright, good and bad, bitter and sweet aspects of life through the heroic heart soul. His inner world which is not expressed in speech comes true.

In short, the Uzbek narratives, having overcome, the stage of development, now have a completely new 


\begin{tabular}{|c|c|c|c|c|c|c|}
\hline \multirow{4}{*}{ Impact Factor: } & ISRA (India) & $=3.117$ & SIS (USA) & $=0.912$ & ICV (Poland) & $=6.630$ \\
\hline & ISI (Dubai, UAE & $=0.829$ & РИНЦ (Russia & $=0.156$ & PIF (India) & $=1.940$ \\
\hline & GIF (Australia) & $=0.564$ & ESJI (KZ) & $=8.716$ & IBI (India) & $=4.260$ \\
\hline & JIF & $=1.500$ & SJIF (Morocce & $=5.667$ & OAJI (USA) & $=0.350$ \\
\hline
\end{tabular}

look. They describe the formation of contemporary people's outlook and thoughts as a human.

\section{References:}

1. Abramovich, G. L. (1953). Vvedenie $v$ literaturovedenie. Moskva. Prosvesheniya.

2. Abrorov, A. (1973). O'zbek povesti. Toshkent: Fan.

3. Belinskiy, V. G. (1978). Sobranie sochineniy. T №3. Moskva: Nauka.

4. Lixachev, L. S. (1984). Neravnodushnaya proza. Moskva: Xudojestvennaya literature.

5. Mirvaliev, C. (1969). O'zbek romani. Toshkent: Fan.

6. Normatov, U. (1974). Nasrimiz ufqlari. Toshkent: G'afur G'ulom nomidagi Adabiyot va san'at.

7. Polovenchenko (1964). Vvedenie v literaturovedenie. Moskva: Visshaya shkola.

8. Sulton, I. (2005). Adabiyot nazariyasi. Toshkent: O'qituvchi.
9. Sulton, I. (1979). Adabiyot nazariyasi. Ikki tomlik. Toshkent: Fan.

10. Ulug'ov, A. (1987). Hozirgi o'zbek qissachiligi. Toshkent. O'zbekiston.

11. Ulug'ov, A. (1991). Qissachiligimiz qirralari. Toshkent: O'qituvchi.

12. Shipilova. (1956). Vvedenie v literaturovedenie, Moskva: Uchpedgaz.

13. Qozixo'jaev, A. (2012). Qissa janri xususida / XX asr o'zbek adabiyoti masalalari. Toshkent. Fan.

14. Quronov, D. (2018). Adabiyot nazariyasi asoslari. Toshkent: Navoiy universiteti.

15. Hotamov, H., \& Sarimsoqov, B. (1983). Adabiyotshunoslik terminlarining ruschao'zbekcha izohli lug'ati. Toshkent: O'qituvchi. 